\title{
Mapping Indonesia’s Competitiveness and Specialization with Its Major Trading partners
}

\author{
Rufita Sri Hasanah ${ }^{1}$ \\ Kementerian Perencanaan Pembangunan Nasional/Bappenas - Indonesia
}

\begin{abstract}
Abstraksi
Seiring dengan perkembangan ekonomi global yang memberikan dampak pada prospek pertumbuhan ekonomi Indonesia, pemetaan terhadap daya saing dan spesialisasi perdagangan dengan mitra dagang utama Indonesia sangat penting untuk menentukan pola perdagangan antar negara. Studi ini berfokus untuk menggali keunggulan komparatif komoditas Indonesia dengan mitra dagang utama sehingga dapat diketahui sektor-sektor unggulan yang menjadi penyumbang pertumbuhan ekonomi. Studi ini menggunakan analisis model perdagangan yang terdiri dari model gravitasi, Richardian model, Heckscher-Ohlin model, Standard Trade model, dan New Trade model untuk menganalisis pola perdagangan Indonesia dengan mitra dagang utama.
\end{abstract}

Kata Kunci: daya saing, spesialisasi, perdagangan, keunggulan komparatif

${ }^{1}$ Rufita Sri Hasanah is a Planning Staff at Planning staff at the Directorate of Macro Planning and Statistical Analysis, Ministry of National Development Planning/Bappenas RI. Email: rufita.hasanah@,bappenas.go.id 


\title{
Mapping Indonesia's Competitiveness and Specialization with Its Major Trading partners
}

\author{
Rufita Sri Hasanah
}

\section{Introduction}

Following an oil price shock in the mid-1980s, Government of Indonesia implemented trade liberalization policy reform by replacing import substitution strategy to promoting export. This progressive reform has played important role to the development and global trade. During pre-crisis in 1998, Indonesia's GDP grew at 7.2 percent on average, recognized as one of the highest growth rates in its region (Goeltom, 2008). As market become more integrated, Indonesian trade openness rose dramatically from 28.68 percent in 1970 to 58.56 percent in 2008 before global financial crisis (World Bank, 2018). In line with the rise of degree openness, the value of Indonesian export also rose rapidly. However, global financial crisis has decreased the demand of Indonesia's export due to weak global economic growth. Papanek, Basri, and Schydlowsky (2009) examined the sharp decline in export was mostly due to the changes in price rather than volume. Rahmaddi and Ichihashi (2012) found that Indonesia's export was weaken by negative share of commodity structure and market distribution. Revealed Comparative Advantage (RCA) suggests that Indonesia exports manufacture good that specialize in natural resource-intensive and unskilled labor-intensive, that has slower world demand growth compared to those commodities with high technology-intensive.

According to Observatory of Economic Complexity (OEC), Indonesian export is on the top $25^{\text {th }}$ in the world and rank $71^{\text {st }}$ as the most complex economy. In 2018. Indonesia exported USD180.75 billion and imported USD188.71 billion, yielding a negative trade balance of USD 8.5 billion. Regardless of the effort to be the key player in global value chain and the fact that higher value-added sectors such as chemical, machinery, and processed wood grow stronger, the top five export products still heavily depend on natural resourceintensive and unskilled labor-intensive commodities. The top five exports of Indonesia consist of coal, palm oil, textile, base metal product, and natural gas. While mineral fuels, machinery, electrical equipment, steel, and plastic become top five of Indonesian import.

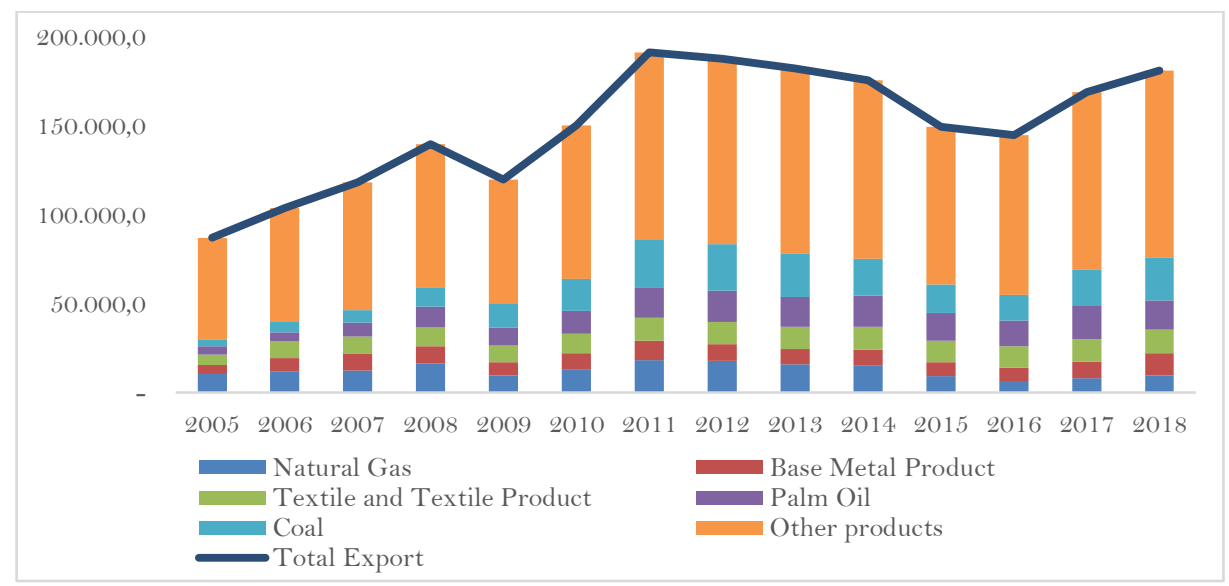

Figure 1. Value of Indonesian Export by Commodity (USD Million) Source: Bank Indonesia

As Indonesia belongs to the top $20^{\text {th }}$ world's largest economy (G20), the trade policy would largely affect the development of this country. Therefore, an assessment on the 
suitable trade models between its trading partners would contribute to the improvement of economic growth. This essay will examine trade relationship between Indonesia and its major trading partners such as China, Australia, and United States (USA) by analyzing different trade models. The analysis will be based on data descriptive and cover the examination of 5 types trade models, namely Gravity model, Ricardian model, HeckscherOhlin, Standard Trade model, and New Trade model to investigate the pattern of trade between Indonesia and its major trading partners.

\section{Indonesia and China Trade's Pattern}

China has become the largest trading partner for both Indonesian export and import. It is recorded that Indonesian export to China remained in an upward trend for several past years, from USD6.78 billion in 2005 rose rapidly to USD26.80 billion in 2018. Similar with export, import from China to Indonesia also showed an increase trend, from USD6.69 billion in 2005 to USD43.69 billion in 2018 (Bank Indonesia, 2019). Based on the gravity model, the volume of trade between countries who engage in international trade depends on the size of its country. This theory is based on notion that the countries that have larger economic size would likely produce more outputs and sell them in global market. Furthermore, higher income in large countries is one of the factors that driven them to be able to purchase goods and services from foreign countries. Moreover, this theory also suggests that the distance between two countries play important role in determining the volume of the trade.

Table 1. Export, Import, Trade Balance, and Size of Economy of Indonesia's 4Trading Partners

\begin{tabular}{|l|c|c|c|c|c|c|c|c|}
\hline \multirow{2}{*}{ Countries } & \multicolumn{4}{|c|}{ Q017 (Billion USD) } & \multicolumn{4}{c|}{ 2018 (Billion USD) } \\
\cline { 2 - 10 } & Export & Import & Trade Balance & GDP & Export & Import & Trade Balance & GDP \\
\hline China & 23.41 & 34.29 & $(10.89)$ & $12,143.00$ & 26.79 & 43.69 & $(16.89)$ & $13,608.00$ \\
\hline Japan & 16.88 & 15.36 & 1.52 & $4,680.00$ & 18.78 & 18.30 & 0.48 & $4,971.00$ \\
\hline US & 17.74 & 8.15 & 9.59 & $19,485.00$ & 18.46 & 10.06 & 8.4 & $20,494.00$ \\
\hline Singapore & 12.87 & 18.20 & $(5.33)$ & 338.41 & 13.80 & 24.26 & $(10.46)$ & 364.16 \\
\hline India & 14.00 & 3.98 & 10.02 & $2,653.00$ & 13.72 & 4.64 & 9.08 & $2,726.00$ \\
\hline South Korea & 7.33 & 8.35 & $(1.02)$ & $1,531.00$ & 9.21 & 9.37 & $(0.17)$ & $1,619.00$ \\
\hline Malaysia & 8.30 & 8.72 & $(0.42)$ & 314.71 & 9.04 & 8.79 & 0.25 & 354.35 \\
\hline Thailand & 6.31 & 9.04 & $(2.73)$ & 455.28 & 6.70 & 10.55 & $(3.86)$ & 504.99 \\
\hline
\end{tabular}

Source: Bank Indonesia

The Gravity theory seems able to explain the trade pattern between Indonesia and China. Given the data above, it shows the trade statistics of major trading partners for Indonesia that suggests the trade volume between Indonesia and China is attracted by the size of the countries as well as the distance between these two countries. The top three of Indonesia's largest trading partners are dominated by large size countries, reflected by high amount of GDP. Moreover, Given the fact that China and Indonesia are considered as Asian countries, both countries share relatively same culture, therefore many products of two countries are more suitable for each other which boost trade activities among them. Additionally, trade agreements between Indonesia and China also play significant role to increase trade volume between them. Chandra and Lontoh (2011) examined the free trade agreement between ASEAN and China (ACFTA) have affected the improvement of the total trade volume between Indonesia and China. 
The trade relationship between two countries should be analyzed further in terms of sectoral composition to capture how the trade occurred among them. Data from World Integrated Trade Solution (WITS) World Bank revealed that the top three export commodities from Indonesia to China are mainly considered as primary commodities. Mining products, particularly fuel, vegetables, and wood were the biggest commodities of Indonesian export to China, which accounted for 30.45 percent, 17.97 percent, and 12.46 percent of total export. On the other side, the top three commodities of China's export were machinery and electricity, metals, and textiles and clothing, which accounted for 35.58 percent, 12.71 percent, and 12.21 percent of total export. Looking at this trade pattern, it seems that Heckscher-Ohlin (HO) model is also suitable to explain the trade among them, particularly for these top three export sectors in Indonesia and China. As mentioned previously, Indonesia's production based on natural resource and unskilled labor intensive, while some studies argue that China is in transition from resource-and labor-intensive to capital- and technology-intensive export (Caporale, Sova, \& Sova, 2015). This fact signifies the validity of HO model that countries would likely sell goods abroad whose production is intensive in factors in which the countries are abundantly endowed. Both of mining products and vegetables depend on natural resource which become the largest export to China, while machinery and electricity and metal become the largest export to Indonesia from China in which the production heavily depend on technology-intensive.

Table 2. Share of Export (\%) and Revealed Comparative Advantage in 2017

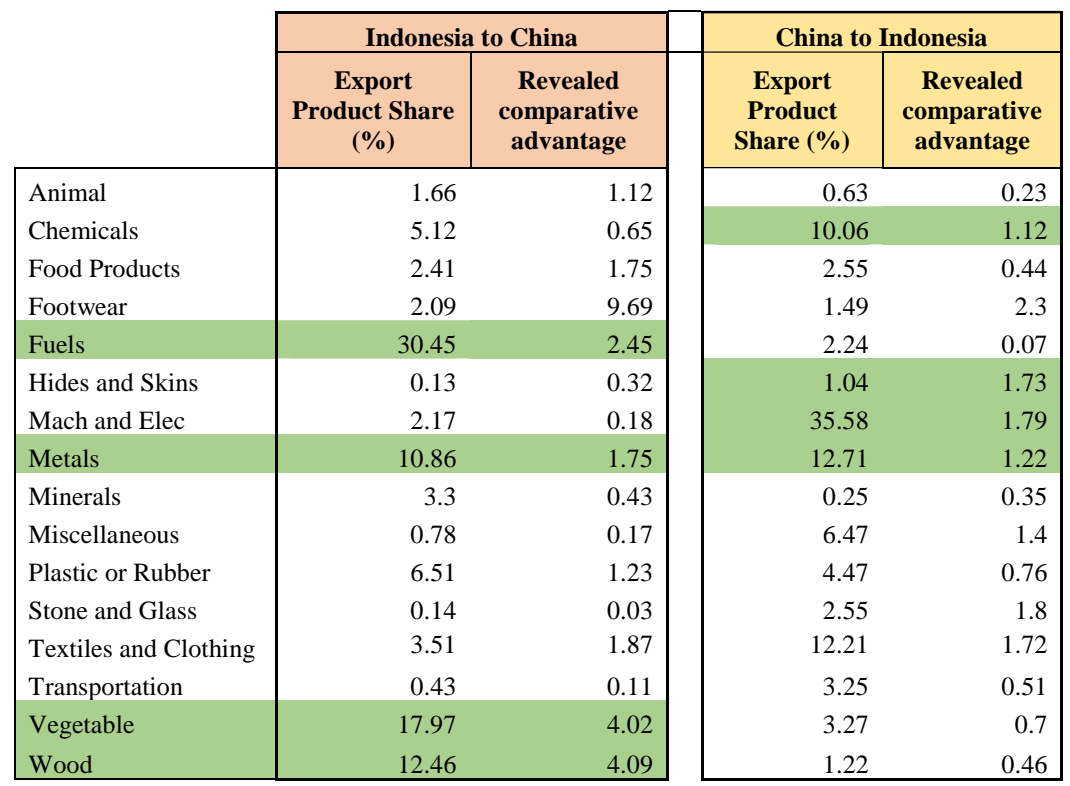

Source: World Integrated Trade Solution (WITS), World Bank

\section{Indonesia and Australia Trade’s Pattern}

As the neighbor country, trade relationship between Indonesia and Australia is very substantial. Trade bilateral agreement between two countries also signifies the importance of trade relationship between them. Australia became $13^{\text {th }}$ largest export destination for Indonesia which account for USD2.73 billion in 2018. Similarly, Indonesia was also $13^{\text {th }}$ largest trading partner for Australia, which more than USD4.70 billion of goods exported to Indonesia in 2018. These two economies have supplied complementary goods to each other. Indonesia exports wide varieties of natural resource-intensive and labor-intensive 
products such as mining products, wood, textile and clothing. While Australia mostly exported goods which produced based on land abundance and natural-resource intensive such as live animals, vegetables, and minerals. Moreover, both countries trade crude oil for each other. Based on observation of export sectoral composition for Indonesia and Australia, it can be concluded that both countries follow HO model for its trade pattern in which these two economies export goods that endowed abundantly and produce intensively.

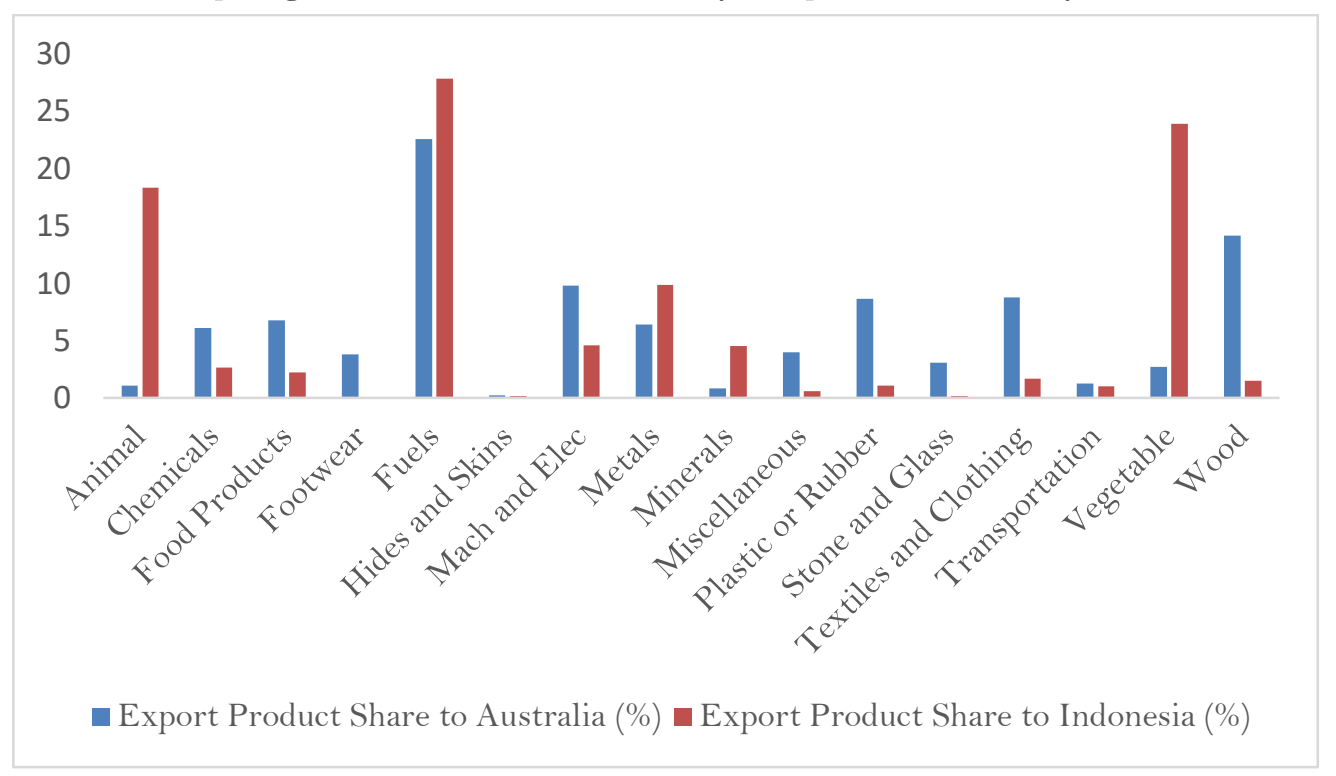

Figure 2. Export Product Share 2018 (\%)

Source: World Integrated Trade Solution (WITS), World Bank

Interestingly, both countries export same products under category fuels. Based on UN Comtrade data, Indonesia imported USD629.53 million and exported USD550.84 million of crude oil. While Australia also imported USD840.46 million and exported USD629.35 million of crude oil. This pattern of international trade between these two countries would likely follows New Trade Theory model. In this theory, two similar economies can also acquire the gain from trade by engaging trading in similar goods or intra-industry trade. This theory is the extension from Ricardo's principle and HO model which postulate trade among countries occur due to different level of resource endowments and intensity of factor production. The distinction between these two models lies on the factors that drive them to engage trade activities. Comparative advantage is the main driver why both countries engage in inter-industry trade, while economies of scale is the main factors of countries conduct intra-industry trade. Herb Grubel and Peter Lloyd developed formulation of IIT index in 1971 to measure the level of intra-industry. The value of IIT index as follow:

$$
\begin{aligned}
& G L_{\text {Indonesia }}=1-\frac{|\$ 550.84 B-\$ 629.53 B|}{\$ 550.84 B+\$ 629.53 B}=0.93 \\
& G L_{\text {Australia }}=1-\frac{|\$ 629.35 B-\$ 840.46 B|}{\$ 629.35 B+\$ 840.46 B}=0.86
\end{aligned}
$$

This high number of IIT index reflect large amount of intra-industry trade in crude oil sector. This implies that crude both countries import and export the same category of products, but it might have different content of value added. As New Trade Theory discuss 
that trade within industry is driven by imperfect market competition, each country will export a wide range of products and import a different range variety of the same products which has product differentiation. In this case, Kimura and Chen (2018) argue that technology is important in affecting the process of value chains in which the economies would likely gain its competitiveness.

\section{Indonesia and USA Trade's Pattern}

In 2018, United States was Indonesia's third largest trading partner, with total export in goods valued USD18.46 billion and total import in goods valued USD10.06 billion. Meanwhile, Indonesia was the $26^{\text {th }}$-largest trading partner for United States. As the total export from Indonesia to USA increased double since 2005 to 2018 , while the total import had slowly increased, Indonesia trade surplus with USA is wider, reaching USD8.4 billion in 2018. WITS World Bank reported the top five export commodities from Indonesia to USA includes textiles and clothing, plastic and rubber, vegetable, machinery and electricity, and footwear, while vegetable, machinery and electricity, chemicals, food products, and textiles and clothing become the largest import commodities.

Table 3. Share of Export (\%) and Revealed Comparative Advantage in 2017

\begin{tabular}{|l|r|r|r|r|r|r}
\cline { 2 - 8 } & \multicolumn{3}{|c|}{ Indonesia - USA } & \multicolumn{3}{c}{ USA - Indonesia } \\
\cline { 2 - 8 } & $\begin{array}{c}\text { Export } \\
\text { Product } \\
\text { Share (\%) }\end{array}$ & $\begin{array}{c}\text { Revealed } \\
\text { comparative } \\
\text { advantage }\end{array}$ & $\begin{array}{c}\text { GL } \\
\text { Index }\end{array}$ & $\begin{array}{c}\text { Export } \\
\text { Product } \\
\text { Share (\%) }\end{array}$ & $\begin{array}{c}\text { Revealed } \\
\text { comparative } \\
\text { advantage }\end{array}$ & $\begin{array}{c}\text { GL } \\
\text { Index }\end{array}$ \\
\hline Animal & 7.05 & 4.5 & 0.31 & 3.55 & 1.84 & 0.32 \\
\hline Chemicals & 1.52 & 0.16 & 0.42 & 11.02 & 1.22 & 0.54 \\
\hline Food Products & 5.91 & 2.06 & 0.91 & 10.89 & 2.03 & 0.77 \\
\hline Footwear & 9.17 & 6.74 & 0.03 & 0.46 & 0.79 & 0.03 \\
\hline Fuels & 3.89 & 0.52 & 0.81 & 4.11 & 0.32 & 0.46 \\
\hline Hides and Skins & 1.05 & 1.96 & 0.19 & 0.24 & 0.51 & 0.12 \\
\hline Mach and Elec & 9.52 & 0.34 & 0.82 & 12.33 & 0.62 & 0.58 \\
\hline Metals & 3.45 & 0.56 & 0.53 & 3.11 & 0.26 & 0.49 \\
\hline Minerals & 0 & 0.01 & 0.01 & 0.55 & 0.33 & 0.03 \\
\hline Miscellaneous & 6.28 & 0.64 & 0.47 & 5.72 & 1.30 & 0.37 \\
\hline Plastic or Rubber & 11.2 & 3.33 & 0.29 & 3.67 & 0.68 & 0.19 \\
\hline Stone and Glass & 1.32 & 0.43 & 0.40 & 0.24 & 0.46 & 0.10 \\
\hline Textiles and Clothing & 24.24 & 4.93 & 0.24 & 8.43 & 1.38 & 0.21 \\
\hline Transportation & 1.00 & 0.07 & 0.54 & 8.81 & 1.09 & 0.52 \\
\hline Vegetable & 10.93 & 4.60 & 0.96 & 20.31 & 4.09 & 0.77 \\
\hline Wood & 3.47 & 1.68 & 0.89 & 6.57 & 2.5 & 0.78 \\
\hline
\end{tabular}

Source: World Integrated Trade Solution (WITS), World Bank

Moreover, based on revealed comparative advantage analysis, it suggests that Indonesia has comparative advantage in animal, footwear, machinery and electricity, plastic or rubber, and textile and clothing since the RCA exceed the unity and larger than USA RCA. The share of export in these products also higher than the share of export in USA. This implies that the trade pattern for Indonesia mostly rely on unskilled labor-intensive such as footwear and textile and clothing and also primary products, such as animal and plastic or rubber. Baldwin's (2016) developed unbundling framework that examine the evolving of unbundling process. At the first bundling, trade occurs based on specialization in industries in which they have comparative advantage. Once the production is internationally fragmented, the production process moves to gain second bundling when it focuses on the task-wise. This production type mostly occurs in manufacture production, such as machinery and electricity industries where intra-industry trade exists. 
Based on Grubel and Llyod (GL) index, vegetable have high GL index. Moreover, these products have large share of total export, that takes up to 10.93 percent for Indonesian export and 20.31 percent for USA export. This trade pattern indicates that Indonesia and USA engage trading within in vegetable industries. However, based on classification HS 2 digits UN Comtrade data, products under category lac; gums, resins and other vegetable saps and extracts vegetable plaiting materials have high number of GL index since the value of export and import are relatively the same. Trading in these commodities confirms the theory of New Trade model that occur due to economies of scale and imperfect market competition.

Table 3. Share of Export (\%) and Revealed Comparative Advantage in 2017

\begin{tabular}{|c|c|c|c|c|}
\hline \multirow[b]{2}{*}{$\begin{array}{l}\text { HS } \\
\text { Code }\end{array}$} & \multirow[b]{2}{*}{ HS Classification } & \multicolumn{3}{|c|}{ Indonesia - US } \\
\hline & & $\begin{array}{l}\text { Import } \\
\text { product } \\
\text { share (\%) }\end{array}$ & $\begin{array}{c}\text { Export } \\
\text { Product } \\
\text { Share (\%) }\end{array}$ & $\begin{array}{c}\text { GL } \\
\text { index }\end{array}$ \\
\hline 06 & $\begin{array}{l}\text { Trees and other plants, live; bulbs, roots and } \\
\text { the like; cut flowers and ornamental foliage }\end{array}$ & 0.00 & 0.04 & 0.00 \\
\hline 07 & $\begin{array}{l}\text { Vegetables and certain roots and tubers; } \\
\text { edible }\end{array}$ & 1.14 & 0.12 & 0.18 \\
\hline 08 & $\begin{array}{l}\text { Fruit and nuts, edible; peel of citrus fruit or } \\
\text { melons }\end{array}$ & 7.26 & 1.70 & 0.36 \\
\hline 09 & Coffee, tea, mate and spices & 0.16 & 29.15 & 0.01 \\
\hline 10 & Cereals & 19.40 & 0.01 & 0.00 \\
\hline 11 & $\begin{array}{l}\text { Products of the milling industry; malt, } \\
\text { starches, inulin, wheat gluten }\end{array}$ & 0.24 & 0.01 & 0.08 \\
\hline 12 & $\begin{array}{l}\text { Oil seeds and oleaginous fruits; miscellaneous } \\
\text { grains, seeds and fruit, industrial or medicinal } \\
\text { plants; straw and fodder }\end{array}$ & 70.87 & 0.86 & 0.02 \\
\hline 13 & $\begin{array}{l}\text { Lac; gums, resins and other vegetable saps } \\
\text { and extracts }\end{array}$ & 0.53 & 0.71 & 0.90 \\
\hline 14 & $\begin{array}{l}\text { Vegetable plaiting materials; vegetable } \\
\text { products not elsewhere specified or included }\end{array}$ & 0.01 & 0.02 & 0.69 \\
\hline 15 & $\begin{array}{l}\text { Animal or vegetable fats and oils and their } \\
\text { cleavage products; prepared animal fats; } \\
\text { animal or vegetable waxes }\end{array}$ & 0.39 & 67.38 & 0.01 \\
\hline
\end{tabular}

Source: UN Comtrade

\section{Conclusion}

The examination of trade relationship with major trading partners plays important role in determining the gain of trade for the countries that engaging in international trade. One approach to conduct this identification of trade relationship is by analyzing trading partners country profile data such as the size of the economy, the distance, trade agreements between two countries, and the sectoral composition of export and import. Understanding the data of country profile would likely contribute to the utilization of trade model properly.

In conclusion, the trade between Indonesia and its chosen major trading partners, such as China, Australia, and USA follow Heckscher Ohlin (HO) model as the sectoral composition export and import data suggest that each country exported the product that endowed abundantly and produced intensively. However, by observing the size of economies and distance between countries, it revealed that trade relation between Indonesia and China follows gravity model. Moreover, higher share of export and import in crude oil industry between Indonesia and Australia suggest that the trade pattern follows new trade industry which signifies the intra-industry trade. 


\section{Reference List}

Baldwin, R. (2016). The great convergence: Information technology and the new globalization. The Belknap Press of Harvard University Press.

Bank Indonesia. (2019). Value of Exports by Country of Destination. Retrieved from https://www.bi.go.id/en/statistik/seki/terkini/eksternal/Contents/Default aspx

Caporale, G. M., Sova, A., \& Sova, R. (2015). Trade flows and trade specialisation: The case of China. China Economic Review, 34(1), 261-273.

Chandra, A. C., \& Lontoh, L. A. (2011). Indonesia - China trade relations: The deepening of economic integration amid uncertainty?. Interntaional Institute for Sustainable Development.

Goeltom, M. S. (2008). Capital Flows in Indonesia: Challenges and Policy Responses. Bank for International Settlements, 44(1), 265-288.

Kimura, F., \& Chen, L. (2018). Value chain connectivity in Indonesia: The evolution of unbundlings. Bulletin of Indonesian Economic Studies, 54(2), 165-192.

Papanek, G., Basri, M. C., \& Schydlowsky, D. (2009). The impact of world recession on Indonesia and appropriate policy response: Some lesson for Asia. Asian Development Bank Report.

Rahmaddi, R., \& Ichihashi, M. (2013). The role of foreign direct investment in Indonesia's manufacturing exports. Bulletin of Indonesian Economic Studies, 49(3), 329-354.

The Observatory of Economic Complexity. (2019). Economic Complexity Ranking. Retrieved from https://oec.world/en/profile/country/idn/

UN Comtrade. (2018). Trade Data. Retrieved from https://comtrade.un.org/Data/

World Bank. (2018). Trade (\% of GDP). Retrieved from https://data.worldbank.org/indicator/NE.TRD.GNFS.ZS?locations=ID

World Integrated Trade Solution - World Bank. (2017). Indonesia Product exports and imports from China 2017. Retrieved from https://wits.worldbank.org/CountryProfile/en/Country/IDN/Year/2017/ TradeFlow/EXPIMP/Partner/CHN/Product/all-groups

World Integrated Trade Solution - World Bank. (2017). Indonesia Product exports and imports from Australia 2017. Retrieved from https://wits.worldbank.org/CountryProfile/en/Country/IDN/Year/2017/ TradeFlow/EXPIMP/Partner/AUS/Product/all-groups

World Integrated Trade Solution - World Bank. (2017). Indonesia Product exports and imports from United States 2017. Retrieved from https://wits.worldbank.org/CountryProfile/en/Country/IDN/Year/2017/ TradeFlow/EXPIMP/Partner/USA/Product/all-groups 